\title{
Quality assessment of diabetes care according to the recommendations of the St. Vincent Declaration: a population-based study in a rural area of Austria
}

\author{
I.Mühlhanser ${ }^{1}$, M. Sulzer ${ }^{2}$ and M. Berger ${ }^{1}$ \\ ${ }^{1}$ Abteilung für Stoffwechsel und Ernährung (WHO-Collaborating Center for Diabetes), Medizinische Klinik der \\ Heinrich-Heine-Universität Düsseldorf, Düsseldorf, FRG, and ${ }^{2}$ Außenstelle des Ludwig-Boltzmann-Instituts für Klinische \\ Endokrinologie, Pinkafeld, Austria
}

\begin{abstract}
Summary. Using a mobile ambulance the quality of diabetes care was evaluated, according to the recommendations of the St. Vincent Declaration, in $95 \%$ of all known diabetic patients $(n=395)$ in a geographically defined rural area of Austria with 7871 inhabitants. Fourteen of the 395 patients had Type 1 (insulin-dependent) diabetes with age at onset of diabetes below 30 years. Of the 375 patients examined (women $61 \%$, age $66 \pm 13$ years, median diabetes duration 6 years) $16 \%$ were treated with insulin and $47 \%$ with oral agents; $\mathrm{HbA}_{1 \mathrm{c}}$ levels were $7.3 \pm 1.7 \%$. Prevalence of known hypertension was $54 \%$; $68 \%$ of these patients had their blood pressure uncontrolled (systolic $\geq 160$ and/or diastolic $\geq 95 \mathrm{~mm} \mathrm{Hg}$ ); a further $15 \%$ of patients with previously unknown hypertension had blood pressure values of $\geq 160$ and/or $\geq 95 \mathrm{~mm} \mathrm{Hg}$. Urinary albumin concentrations of $>200 \mathrm{mg} / \mathrm{l}$ were found in $15 \%$ of patients, $2 \%$ had a serum creatinine level of $>177 \mu \mathrm{mol} / 1$, no patient had renal replacement therapy. Six patients $(1.5 \%)$ were blind. Screening for retinopathy identified six patients (out of 317 in whom the re-
\end{abstract}

tina could be evaluated) for whom consultation with an ophthalmologist as soon as possible was recommended. Of the total patient group $(n=395) 20$ patients $(5 \%)$ had foot complications (amputations and/or ulcers): 14 patients had a total of 21 lower limb amputations (eight above knee, six below knee, seven below ankle); eight of these 14 patients lived in a nursing home; 11 patients had a total of 13 foot ulcers. In conclusion, in this diabetic population quality of diabetes care was satisfactory with respect to glycaemic control, whereas the high rates of uncontrolled hypertension and above ankle amputations appear amenable to improvement. This study shows that through systematic assessment of the quality of diabetes care specific local needs and deficiencies can be identified in order to propose respective interventions in health care practices.

Key words: Diabetes, eye complications, foot complications, neuropathy, hypertension, quality of care, patient education, general practice, hospitalisation, severe hypoglycaemia.
Representatives of government health departments and patient organizations from all European countries met with diabetes experts under the aegis of the Regional Offices of the World Health Organization and the International Diabetes Federation in St. Vincent, Italy in October 1989. The meeting led to the St. Vincent Declaration, a statement of intents and recommendations to implement policies to reduce morbidity and mortality from diabetes. Some of the major targets are to reduce new blindness due to diabetes by one third or more, to reduce numbers of people entering end-stage diabetic renal failure by at least one third, and to reduce by one half the rate of limb amputations for diabetic gangrene. In order to implement these demanding tasks the St. Vincent Declaration urges quality audit of diabetes health care to be performed at regional and national levels [1]. Following the recommendations of the St. Vincent Declaration we initiated a pilot project in order to assess the quality of diabetes care in a rural area of Austria. The primary aim of the study was to examine all known diabetic patients within a geographically defined area.

\section{Subjects and methods}

The study was performed in the community of Pinkafeld/Wiesfleck/Riedlingsdorf, in the Federal State of Burgenland, Republic of Austria. In 1989/1990 the community had 7871 inhabitants (53\% women; age: less than 15 years $17 \%, 15$ to less than 60 years $62 \%$, 60 years or more $21 \% ; 7 \% 75$ years or more); sex and age distributions were comparable to those of the Burgenland and of the total population of Austria [2]. Primary health care for the community was provided by four general practitioners (one of them being M.S.). These physicians also provided all aspects of diabetes care, except for eye examinations, which are carried out by consultant ophthalmologists. For particular cases patients could be referred to two specialized diabetes clinics approximately 200 kilometres away. 


\section{Identification of persons with diabetes}

Firstly, the proportion of inhabitants who had consulted one or more of the four family physicians during the preceding 3 years was assessed by analysing all patient records at the physicians' offices and verifying them against the community registration lists; $52 \%$ had been registered in at least one practice, $30 \%$ in two, $5 \%$ in three, and $0.2 \%$ in all four practices; only for $13 \%$ of the entire population of the community had no consultation been documented during the preceding 3 years. Secondly, all patient charts were reviewed for identification of the persons with diabetes. A person was classified as having diabetes either if there was current or previous treatment with antidiabetic drugs, or if WHO criteria for diabetes were fulfilled [3], or - in case only a single abnormal blood glucose level [3] was documented - if the level of glycosylated haemoglobin was elevated. Patients with uncertain diabetes, e.g. those with a single abnormal blood glucose measurement, were also identified. All analyses of patient records were done by two trainee physicians under supervision of the general practitioners. All identified persons were invited, at short notice by one of the four physicians, to participate in the examinations. The study was approved by the local medical association and was performed according to the Helsinki declaration of 1983.

\section{Examination of the patients}

All examinations were performed within 6 weeks by a team of two physicians (I.M. and M.B.) and a specially trained diabetes nurse from Düsseldorf using a mobile ambulance. The Mercedes van, donated by Boehringer Mannheim (Mannheim, FRG) was converted to allow the mounting of a non-mydriatic CR4-45NM eye camera (Canon Europe, Amstelveen, The Netherlands), and a dry chemistry laboratory including a Reflotron Reflectance Photometer (Boehringer Mannheim). For about one week (including Saturdays and Sundays) the van was placed close to each of the four practices. Mobile patients were asked to come to the van for examination, immobile patients were visited at their homes.

The examination protocol used an extended and adapted version of a preliminary draft of a data collection sheet prepared by the DO IT (Diabetes care Optimization through Information Technology) EASD Study group for assessment of the quality of diabetes care following the recommendations of the St. Vincent Declaration [a recent version of the data collection sheet is available from Dr. K. Piwernetz, Klinikum Bogenhausen, Englschalkingerstrasse 77, 8000 München, FRG] The investigation of the patients comprised a structured interview, physical examination, fundus photography, and laboratory tests. The interview included questions concerning previous episodes of hyperglycaemic emergencies treated in hospital, severe hypoglycaemia (requiring third party assistance with treatment with i.v. glucose or glucagon injection), history of stroke and myocardial infarction, previous eye examinations and eye diseases, and symptoms indicative of distal symmetrical polyneuropathy. Height and body weight were assessed with the patients wearing light clothes and without shoes. Blood pressure was measured twice in the sitting position at the end of the examination by the nurse using a standard sphygmomanometer according to WHO recommendations; the mean of the two measurements was used for analysis. Examination of the feet included palpation of pulses and screening for sensation loss using the Rydel-Seiffer Tuning Fork as described by Liniger et al. [4]; accordingly, a subject was considered at risk for the development of lower limb ulcerations if the tuningfork score was equal to or less than four on one or both first metatarsals. In the case of a foot lesion or an ulcer, a photograph was taken for documentation. Non-mydriatic retinal photography using a Polaroid film 600 was performed as previously described $[5,6]$ in all patients able to walk into the van. In cases where the pupils did not sufficiently dilate, whenever possible, pharmacological mydriasis was induced with $1 \%$ tropicamide eye drops. In all subjects a macula centred photograph was obtained of one eye. If there was any hint of retinopathy on this first photograph, a picture of the other retina was taken as well. All photographs were additionally examined by two independant experts in Düsseldorf. In patients not able to walk into the van fundoscopy was performed by one of us (M.B.) or, if available, the report of a recent examination by an ophthalmologist was used. A random venous blood sample was taken for immediate determination of serum concentrations of glucose, cholesterol, HDL-cholesterol, triglycerides, and uric acid. Serum was stored at $-20^{\circ} \mathrm{C}$ for later determination of serum creatinine in patients with urinary albumin concentrations of more than $200 \mathrm{mg} /$; for determination of $\mathrm{HbA}_{\mathrm{lc}}$ values a capillary blood sample was taken using the Diamat $\mathrm{HbA}_{10}$ Test system (München, FRG). The specimens were sent to Diusseldorf for analysis with the Bio-Rad Diamat analyser within 3 days. The normal range of the method is 4.6 to 6.0 (SD $0.35 \%$ ), coefficient of variation less than $2 \%$. Urine-analysis was performed in a fresh sample of urine with the Combur q dry chemistry test strip (Boehringer Mannheim). In addition, the urine was centrifuged and samples stored at $-20^{\circ} \mathrm{C}$ for later determination of albumin concentrations using a radioimmunoassay as previously described [7] at the Düsseldorf laboratory. A final report about the examinations was sent to the patients and their physicians.

Statistical analysis. All data were analysed at Düsseldorf University. Data are presented as means $\pm \mathrm{SD}$, as medians ( $25 \%$ to $75 \%$ quantiles) or as otherwise indicated.

\section{Results}

There were 395 diabetic patients receiving their primary care from the four general practitioners. Based on manifestation of diabetes below age 30 years and the usual clinical criteria [3] 14 of the 395 patients had Type 1 (insulin-dependent) diabetes mellitus. Of the 395 patients $375(95 \%)$ took part in the study; 36 patients $(9 \%)$ were nursing home residents. Figure 1 shows the distributions of current age and age at diagnosis of diabetes of the 375 patients, who participated. Table 1 summarizes further patient characteristics, current treatment, and blood pressure data. Table 2 summarizes the laboratory measurements, and Table 3 the results concerning history of acute metabolic complications, cardiovascular events,

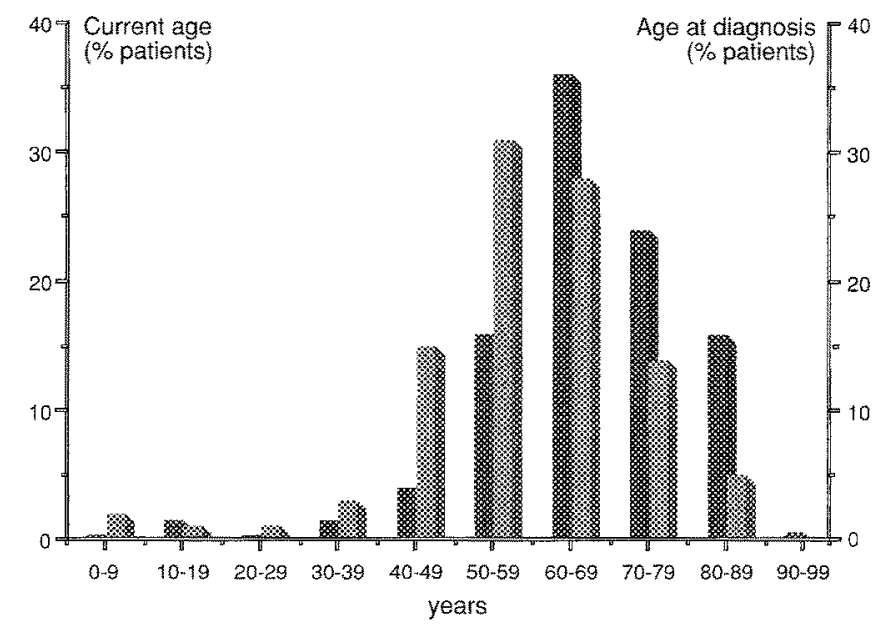

Fig. 1. Percentage distribution of the diabetic patients $(n=375)$ according to current age (black bars) and age at diagnosis of diabetes (grey bars), respectively. The bars indicate the percentages of subjects of the total patient group that fall within each of the age groups presented on the $\mathrm{x}$-axis 
Table 1. Patient characteristics, current treatment and blood pressure data

\begin{tabular}{|c|c|c|c|c|}
\hline & \multicolumn{3}{|c|}{ Diabetic subjects } & \multirow[b]{2}{*}{$\begin{array}{l}\text { Non-diabetic } \\
\text { subjects } \\
(n=123)\end{array}$} \\
\hline & $\begin{array}{l}\text { Age } \\
\leq 60 \text { years } \\
(n=104)\end{array}$ & $\begin{array}{l}\text { Age } \\
>60 \text { years } \\
(n=271)\end{array}$ & $\begin{array}{l}\text { Total } \\
\text { group } \\
(n=375)\end{array}$ & \\
\hline Age (years) & $55(49$ to 58$)$ & $71(66$ to 79$)$ & $67(60$ to 77$)$ & $64(57$ to 72$)$ \\
\hline Females $(\%)$ & 47 & 66 & 61 & 68 \\
\hline Diabetes duration (years) & $5(2$ to 10$)$ & $6(3$ to 14$)$ & $6(2$ to 12$)$ & - \\
\hline Height $(\mathrm{cm})$ & $165 \pm 12$ & $162 \pm 9$ & $163 \pm 10$ & $164 \pm 8$ \\
\hline Body mass index $\left(\mathrm{kg} \cdot \mathrm{m}^{-2}\right)$ & $29 \pm 6$ & $28 \pm 4$ & $28 \pm 5$ & $28 \pm 6$ \\
\hline Past/current smokers (\%) & $25 / 14$ & $17 / 8$ & $19 / 10$ & $18 / 7$ \\
\hline Retired (\%) & 31 & 96 & 78 & 68 \\
\hline $\begin{array}{l}\text { Diabetes treatment (\% patients) } \\
\text { none/diet only } \\
\text { tablets } \\
\text { - sulphonylureas only } \\
\text { - sulphonylureas and biguanides } \\
\text { insulin } \\
\text { - no. of daily injections }\end{array}$ & $\begin{array}{l}14 / 27 \\
40 \\
30 \\
10 \\
19 \\
3 \pm 2\end{array}$ & $\begin{array}{l}15 / 20 \\
49 \\
39 \\
10 \\
15 \\
2 \pm 1\end{array}$ & $\begin{array}{l}15 / 22 \\
47 \\
37 \\
10 \\
16 \\
2 \pm 1\end{array}$ & $\begin{array}{l}- \\
- \\
- \\
- \\
- \\
-\end{array}$ \\
\hline $\begin{array}{l}\text { Additional drugs (\% patients) } \\
\text { for dyslipoproteinaemia } \\
\text { for IHD and/or CF } \\
\text { for hypertension }\end{array}$ & $\begin{array}{r}3 \\
19 \\
39\end{array}$ & $\begin{array}{r}6 \\
43 \\
44\end{array}$ & $\begin{array}{r}5 \\
36 \\
42\end{array}$ & $\begin{array}{r}1 \\
24 \\
36\end{array}$ \\
\hline Systolic BP (mm Hg) & $153 \pm 27$ & $161 \pm 25$ & $159 \pm 26$ & $155 \pm 24$ \\
\hline Diastolic BP (mmHg) & $90 \pm 12$ & $86 \pm 13$ & $87 \pm 13$ & $90 \pm 12$ \\
\hline $\begin{array}{l}\text { Patients (\%) with } \\
\text { known hypertension (of those \% } \\
\text { with controlled hypertension }{ }^{\star} \text { ) } \\
\mathrm{BP} \geq 160 \text { and/or } \geq 95 \mathrm{~mm} \mathrm{Hg} \\
\mathrm{BP} \geq 200 \text { and/or } \geq 115 \mathrm{~mm} \mathrm{Hg}\end{array}$ & $\begin{array}{l}54(38) \\
42 \\
8\end{array}$ & $\begin{array}{l}54(30) \\
55 \\
10\end{array}$ & $\begin{array}{l}54(32) \\
51 \\
10\end{array}$ & $\begin{array}{l}46(41) \\
46 \\
5\end{array}$ \\
\hline
\end{tabular}

Means \pm SD or medians ( $25 \%$ to $75 \%$ quartiles); IHD, ischaemic heart disease; CF, cardiac failure; $B P$, blood pressure.

${ }^{a} \mathrm{BP}<160$ and $<95 \mathrm{~mm} \mathrm{Hg}$

and hospital admissions. No patient had renal replacement therapy. Of the 14 Type 1 diabetic patients 12 could be examined (six women, mean age $23 \pm 15$ years, diabetes duration $13 \pm 11$ years). Their mean $\mathrm{HbA}_{\mathrm{ic}}$ levels were $7.9 \pm 1.8 \%$, and the incidence of severe hypoglycaemia was 0.14 cases per patient per year; four of the 12 patients had non-proliferative retinopathy and an increased urinary albumin concentration.

\section{Foot complications}

Foot pulses were absent uni- or bilaterally in $10 \%$ of the patients aged 60 years or less and in $19 \%$ of the older patients; a vibration sensation score of equal to or less than four was found in $13 \%$ and $31 \%$, respectively; symptoms compatible with peripheral neuropathy were reported by $14 \%$ and $18 \%$, respectively. Of the younger patients two had bilateral below ankle amputations; of the older patients 11 had a total of 15 amputations (eight above knee, four below knee, three below ankle). Of the 13 patients with amputations seven lived in a nursing home. The causes for amputation appeared to be due solely to diabetic neuropathy $(n=3)$, to diabetic neuropathy and peripheral atherosclerotic disease $(n=3)$, mainly due to atherosclerotic disease $(n=4)$, atherosclerotic disease and neuropathy associated with severe alcoholism $(n=1)$, paralysis following cerebral infarction $(n=1)$, and unknown $(n=1)$. In addition, there were two patients with limb amputations due to trauma, not related to their diabetes. Five patients with an amputation and absent vibration sensation additionally had acute ulcers either on one side $(n=3)$ or on both sides $(n=2)$; there were five other patients with one ulcer each, and one patient had a healed plantar ulcer.

\section{Eye complications (Table 4)}

Retinal photography was performed in $97 \%$ of the younger and $93 \%$ of the elderly patients; pupils were dilated in $16 \%$ and $29 \%$, respectively; the retina could not be seen in one younger and 43 elderly patients. Reasons for blindness of both eyes were diabetic retinopathy $(n=2)$, cataract $(n=2)$, or uncertain $(n=2)$, and of a single eye diabetic retinopathy $(n=3)$, diabetic retinopathy and cataract $(n=1)$, cataract $(n=3)$, senile macular degeneration $(n=2)$, trauma $(n=2)$, congenital $(n=2)$, neuritis $(n=1)$, tumour $(n=1)$, thrombosis $(n=1)$, and uncertain $(n=1)$; no proliferations were identified; $49 \%$ of the patients with retinopathy reported having consulted an ophthalmologist because of their 
Table 2. Laboratory measurements

\begin{tabular}{|c|c|c|c|c|}
\hline & \multicolumn{3}{|c|}{ Diabetic subjects } & \multirow[b]{2}{*}{$\begin{array}{l}\text { Non-diabetic } \\
\text { subjects } \\
(n=123)\end{array}$} \\
\hline & $\begin{array}{l}\text { Age } \\
\leq 60 \text { years } \\
(n=104)\end{array}$ & $\begin{array}{l}\text { Age } \\
>60 \text { years } \\
(n=271)\end{array}$ & $\begin{array}{l}\text { Total } \\
\text { group } \\
(n=375)\end{array}$ & \\
\hline Mean $\mathrm{HbA}_{1 \mathrm{c}}(\%)$ & $7.5 \pm 1.7$ & $7.3 \pm 1.7$ & $7.3 \pm 1.7$ & $5.4 \pm 0.3$ \\
\hline $\begin{array}{l}\text { Patients (\%) with } \mathrm{HbA}_{1 c} \\
\quad \leq 6 \% \\
\quad \geq 9 \%\end{array}$ & $\begin{array}{l}17 \\
18\end{array}$ & $\begin{array}{l}25 \\
14\end{array}$ & $\begin{array}{l}23 \\
15\end{array}$ & 100 \\
\hline $\begin{array}{l}\text { Serum measurements } \\
\text { Glucose }(\mathrm{mmol} / \mathrm{l}) \\
\text { Cholesterol }(\mathrm{mmol} / \mathrm{l}) \\
>7.76 \mathrm{mmol} / \mathrm{l}(\% \text { patients }) \\
\text { HDL-cholesterol }(\mathrm{mmol} / 1) \\
\text { Total: HDL cholesterol }>5(\% \text { patients) } \\
\text { Triglycerides (mmol } / 1) \\
\text { Uric acid }(\mu \mathrm{mol} / 1) \\
\text { Creatinine }>177 \mu \mathrm{mol} / 1 \text { (no. patients) }\end{array}$ & $\begin{array}{l}9.5 \pm 4.0 \\
5.72 \pm 1.41 \\
5 \\
1.09 \pm 0.36 \\
57 \\
2(1.5 \text { to } 3.5) \\
324 \pm 102 \\
3\end{array}$ & $\begin{array}{l}9.7 \pm 4.1 \\
5.72 \pm 1.28 \\
6 \\
0.97 \pm 0.31 \\
71 \\
2.5(1.7 \text { to } 3.7) \\
335 \pm 93 \\
5\end{array}$ & $\begin{array}{l}9.6 \pm 4.1 \\
5.72 \pm 1.32 \\
6 \\
1.00 \pm 0.33 \\
67 \\
2.4(1.6 \text { to } 3.6) \\
331 \pm 96 \\
8\end{array}$ & $\begin{array}{l}6.0 \pm 1.1 \\
5.59 \pm 1.11 \\
3 \\
1.11 \pm 0.31 \\
54 \\
1.9(1.3 \text { to } 2.8) \\
339 \pm 101 \\
0\end{array}$ \\
\hline $\begin{array}{l}\text { Urine measurements (\% patients) } \\
\text { Albuminuria } \\
\quad>20 \leq 200 \mathrm{mg} / 1 \\
>200 \mathrm{mg} / 1 \\
\text { Glucosuria } \\
\text { Glucosuria and ketonuria } \\
\text { Leucocyturia and nitrite positive }\end{array}$ & $\begin{array}{r}27 \\
13 \\
46 \\
5 \\
0\end{array}$ & $\begin{array}{r}34 \\
15 \\
39 \\
4 \\
6\end{array}$ & $\begin{array}{r}32 \\
15 \\
41 \\
4 \\
5\end{array}$ & $\begin{array}{r}24 \\
0 \\
4 \\
0 \\
2\end{array}$ \\
\hline
\end{tabular}

Means \pm SD or medians ( $25 \%$ to $75 \%$ quartiles); ${ }^{a}$ measured only in patients with albuminuria $>200 \mathrm{mg} /$

Table 3. History of acute metabolic complications, cardiovascular events and hospital admissions

\begin{tabular}{|c|c|c|c|}
\hline & \multicolumn{2}{|c|}{ Diabetic subjects } & \multirow[b]{2}{*}{$\begin{array}{l}\text { Non-diabetic subjects } \\
(n=123)\end{array}$} \\
\hline & $\begin{array}{l}\text { Age } \leq 60 \text { years } \\
(n=104)\end{array}$ & $\begin{array}{l}\text { Age }>60 \text { years } \\
(n=271)\end{array}$ & \\
\hline \multicolumn{4}{|l|}{ Percent patients with a history of } \\
\hline - hyperglycaemic emergency & $1 \%$ & $1 \%$ & - \\
\hline $\begin{array}{l}\text { - severe hypoglycaemia } \\
\text { of patients treated with insulin } \\
\text { of patients treated with tablets }\end{array}$ & $\begin{array}{r}25 \% \\
7 \%\end{array}$ & $\begin{array}{r}17 \% \\
3 \%\end{array}$ & $\begin{array}{l}- \\
-\end{array}$ \\
\hline $\begin{array}{l}\text { - hospital admissions because of di } \\
\text { ever } \\
\text { lastyear } \\
\text { - hospital days }\end{array}$ & $\begin{array}{l}18 \% \\
5 \% \\
68\end{array}$ & $\begin{array}{l}17 \% \\
7 \% \\
435\end{array}$ & $\begin{array}{l}- \\
- \\
-\end{array}$ \\
\hline $\begin{array}{l}\text { - hospital admissions because of otl } \\
\text { last year } \\
\text { - hospital days }\end{array}$ & $\begin{array}{l}27 \% \\
639\end{array}$ & $\begin{array}{l}21 \% \\
1291\end{array}$ & $\begin{array}{l}20 \% \\
337\end{array}$ \\
\hline - myocardial infarction & $7 \%$ & $13 \%$ & $7 \%$ \\
\hline - cerebral stroke & $4 \%$ & $7 \%$ & $3 \%$ \\
\hline - peripheral bypass/angioplasty & $2 \%$ & $3 \%$ & $1 \%$ \\
\hline
\end{tabular}

diabetes during the preceding year. No patient required immediate referral to an ophthalmologist. Consultation with an ophthalmologist as soon as possible was recommended for six patients. In persons with a known diabetes duration of 5 years or less $(n=180)$, eight $(4 \%)$ had non-proliferative retinopathy and there was no blindness due to diabetic retinopathy; in those with a diabetes duration of 15 years or more $(n=74)$ prevalence of retinopathy was $53 \%$. In the subgroup of patients in whom diabetes was diagnosed above age 60 $(n=159)$ retinopathy was present in only 13 patients
(11\% of 114 patients with retinal evaluation); 12 patients had only mild background retinopathy.

\section{Data related to patient self care}

Of the younger patients $12 \%$ and of the elderly $5 \%$ reported performing blood glucose self-monitoring; $15 \%$ and $8 \%$, respectively, reported performing urine glucose monitoring. Of the insulin-treated patients $(n=62) 55 \%$ performed some kind of metabolic self-monitoring; $25 \%$ 
Table 4. Eye complications

\begin{tabular}{|c|c|c|c|}
\hline & \multicolumn{2}{|c|}{ Diabetic subjects } & \multirow[b]{2}{*}{$\begin{array}{l}\text { Non-diabetic } \\
\text { subjects } \\
(n=123)\end{array}$} \\
\hline & $\begin{array}{l}\text { Age } \\
\leq 60 \text { years } \\
(n=104)\end{array}$ & $\begin{array}{l}\text { Age } \\
>60 \text { years } \\
(n=271)\end{array}$ & \\
\hline $\begin{array}{l}\text { No. of patients reporting } \\
\text { - glaucoma } \\
\text { - cataract } \\
\text { surgery of cataract }\end{array}$ & $\begin{array}{l}5(5 \%) \\
3(3 \%) \\
1(1 \%)\end{array}$ & $\begin{array}{l}11(4 \%) \\
55(20 \%) \\
14(5 \%)\end{array}$ & $\begin{array}{l}4(3 \%) \\
9(7 \%) \\
1(1 \%)\end{array}$ \\
\hline $\begin{array}{l}\text { - photocoagulation } \\
\text { because of diabetes } \\
\text { other reasons }\end{array}$ & $\begin{array}{l}5(5 \%) \\
2(2 \%)\end{array}$ & $\begin{aligned} 12 & (4 \%) \\
7 & (3 \%)\end{aligned}$ & $4(3 \%)$ \\
\hline $\begin{array}{l}\text { - consultation of an ophthalmole } \\
\text { ever } \\
\text { last } 12 \text { months }\end{array}$ & $\begin{array}{l}34(33 \%) \\
23(22 \%)\end{array}$ & $\begin{array}{l}84(31 \%) \\
54(20 \%)\end{array}$ & - \\
\hline - eye surgery (any reason) & $4(4 \%)$ & $22(8 \%)$ & $6(5 \%)$ \\
\hline $\begin{array}{l}\text { - blindness (any reason) } \\
\text { both eyes } \\
\text { one eye }\end{array}$ & $\begin{array}{l}0 \\
4(4 \%)\end{array}$ & $\begin{array}{r}6(2 \%) \\
13(5 \%)\end{array}$ & $\begin{array}{l}0 \\
2(2 \%)\end{array}$ \\
\hline $\begin{array}{l}\text { Examination of the retina (no. of } \\
\text { - retina evaluated } \\
\text { - no diabetic retinopathy } \\
\text { - non-proliferative retinopathy } \\
\text { macular involvement } \\
\text { - preproliferative retinopathy }\end{array}$ & $\begin{array}{l}100(96 \%) \\
78(78 \%)^{\mathrm{a}} \\
21(21 \%)^{\mathrm{a}} \\
3(3 \%)^{\mathrm{a}} \\
0\end{array}$ & $\begin{array}{l}217(80 \%) \\
165(76 \%)^{\mathrm{a}} \\
49(23 \%)^{\mathrm{a}} \\
6(3 \%)^{\mathrm{a}} \\
1(0.5 \%)^{\mathrm{a}}\end{array}$ & $\begin{array}{l}101(82 \%) \\
101(100 \%)^{a} \\
- \\
-\end{array}$ \\
\hline $\begin{array}{l}\text { Blindness because of diabetes } \\
\text { both eyes } \\
\text { one eye }\end{array}$ & $\begin{array}{l}0 \\
2(2 \%)^{\mathrm{a}}\end{array}$ & $\begin{array}{l}2(1 \%)^{a} \\
2(1 \%)^{a}\end{array}$ & - \\
\hline
\end{tabular}

${ }^{\text {a }}$ percentages of patients with retina evaluation

had been trained in the self-adaptation of their insulin dosages, and $61 \%$ carried carbohydrates for the treatment of hypoglycaemia.

\section{Subgroup of patients not examined}

Twenty patients (nine women) either declined to participate $(n=11)$, or an appointment for the examination could not be arranged within the study period $(n=9)$. Their age was $60 \pm 13$ years, seven patients were treated with insulin, 10 with oral antidiabetic agents. One woman (61 years old, insulin-treated) had bilateral below knee amputation because of diabetes and lived in a nursing home. One man ( 71 years old, insulin-treated) was in hospital because of a foot ulcer. None of the patients were blind.

\section{Non-diabetic patients}

A group of 123 patients treated by the four general physicians, in whom a previously suspected diagnosis of diabetes was not confirmed during the study, were also examined. For comparison of profiles of patient characteristics and health care practices some results concerning these patients are presented in Tables 1 to 4 . One subject had traumatic below ankle amputation. One subject had two plantar ulcers following cerebral stroke. Foot pulses were absent in $7 \%$ of subjects; a vibration sensation score of equal to or less than four was found in $13 \%$, and symp- toms compatible with peripheral neuropathy were reported by $4 \%$ of patients.

\section{Discussion}

In the present study $95 \%$ of all known diabetic patients within a geographically defined area were examined according to the recommendations of the St. Vincent Declaration [1]. The prevalence of diabetes was found to be $5 \%$. Previous surveys in Austria [8] and Germany [9] had yielded prevalence rates of about $4 \%$.

There is an almost complete lack of information concerning the overall quality of diabetes care in unselected diabetic populations. Among the few studies that exist $[10-12,14,15]$ the Wisconsin study from the United States is the most comprehensive [10-12]. However, the method used for case ascertainement in that study yielded a diabetes prevalence of only $1 \%$ [10], a certain underestimation in the light of a recent survey from Minnesota reporting rates of about $8 \%$ for Type 2 (non-insulin-dependent) diabetes [13]. In addition, patients institutionalized in nursing homes and disability centres were not evaluated [10]. Likewise, in two smaller European studies $[14,15]$ estimated prevalence rates of diabetes were less than $2 \%$, again indicating bias in patient selection. The differences in the completeness of patient recruitment have to be taken into account when comparisons are made between the findings of the present investigation and other studies. 
In the present study, $1.5 \%$ of the diabetic patients were blind. This estimate for the prevalence of blindness and the role of diabetic retinopathy as a causal factor corresponds well with a recent population-based study from Germany [16]. Markedly higher prevalence rates for diabetic eye disease than in the present investigation have been reported in the Wisconsin study [10-12]. In the present survey only $4 \%$ of patients with a diabetes duration of up to 5 years had non-proliferative retinopathy, whereas in the Wisconsin study in persons who had diabetes for less than 2 years about $26 \%$ had any retinopathy and about $3 \%$ had proliferative retinopathy [11]. Comparable findings have been reported from the United Kingdom Prospective Diabetes Study (UKPDS) of maturity onset diabetes [17]; in that study retinopathy was observed in $24 \%$ of patients within 6 months of diagnosis of diabetes, and of those eyes with retinopathy, more than $3 \%$ had severe preproliferative retinopathy. Apart from the fact that the two latter studies have been particularly focussed upon the detection and progression of diabetic eye disease by applying most sensitive methods for retinal evaluation, whereas our cross-sectional study merely aimed at screening for diabetic retinopathy, there are several factors which appear to contribute to these differences. Due to the characteristics of the health care system diabetes is being diagnosed at an earlier stage in the Austrian patients; the patients in the Wisconsin study were, to a much bigher extent, insulin-treated and they were metabolically considerably less well-controlled than the patients in this study. Taken together, these differences in patient characteristics and data collection may easily explain the increased severity of diabetic eye disease in the Wisconsin study compared to this investigation.

Of the 21 lower limb amputations registered in this survey, as expected about half were predominantly due to peripheral atherosclerotic disease and the other half were mainly due to the sequelae of neuropathic foot complican tions. It is of note that a high percentage of amputations were performed above the knee and below knee with relative infrequent below ankle surgery. Furthermore, neuropathic ulcers were seen in practically all remaining limbs of amputated patients with peripheral neuropathy. Both of these findings should be amenable by applying the multidisciplinary approach for tertiary prevention concerning the diabetic foot syndrome as developed and evaluated by a number of diabetes centres [18-21].

In this survey glycaemic control as judged from $\mathrm{Hb} \mathrm{A}_{i c}$ levels compares favourably with respective data from the Wisconsin study [11] and other reports [14, 15, 22]. Nevertheless, the frequency of severe hypoglycaemia was consistent with comparable data from other studies [23, 24], i.e. there was no indication for an increased risk of hypoglycaemia associated with the relatively low $\mathrm{HbA}_{1 \mathrm{c}}$ levels.

On average, the patients had been hospitalized for 6.5 days during the year preceding the study. Although no systematic data on the frequency of hospitalizations are available for the general population of Austria, these figures indicate increased in-patient treatment for the diabetic population studied when compared with the 123 non-diabetic patients who had been subjected to the survey in this study ( 2.7 hospitalization days during the preceding year). Only about $25 \%$ of the hospital admissions were reportedly due to diabetes, indicating the important role of concomitant diseases and/or complications for the patients' morbidity. In this context, the high prevalence of arterial hypertension and the low percentage of satisfactorily controlled blood pressure values in these patients despite quite extensive antihypertensive medication when compared to the general population of hypertensive subjects [25] represents an important finding of this study. Remarkably, data on the overall quality of hypertension care in diabetic patients are lacking in the literature.

In conclusion, this pilot study describes the methodology and feasibility of a quality assessment of overall diabetes care in unselected patient populations based upon a model project in a geographically-defined population of 395 diabetic patients under the care of four general practitioners in a rural district of Austria. In this pilot project, overall metabolic control compared favourably with similar surveys of diabetic populations. The need for an improvement in diabetes care became particularly apparent with regard to foot care and the prevention of lower limb amputations. The use of oral antidiabetic agents in Type 2 diabetes should be further reduced and the overall quality of antihypertensive therapy needs improvement. An effective intervention to improve these areas of diabetes care should be the implementation of effective systems of structured patient education concerning foot care [18-21], non-drug therapy of Type 2 diabetes [26] and hypertension $[27,28]$. It is only through systematic assessments of the quality of diabetes care, such as conducted in this study in accordance with the policies of the St. Vincent Declaration, that the specific (local) needs and deficiencies can be identified and respective interventions into health care practices can be proposed.

Acknowledgements. For dedicated co-operation we wish to thank Dr. R.Nour, Dr. R.Oblak, Dr. M.Fruhwirth, Dr. H.Lehner, Dr. A.Zadra, Ms. D.Hemmann, Ms. B.Senger, Dr. V.Jörgens, Dr. M. Grüßer, Dr. B. Richter and Dipl. Päd. U.Bott. We thank the Boehringer-Mannheim Company (Mannheim, FRG) for generous financial support.

\section{References}

1. Diabetes care and research in Europe. The Saint Vincent Declaration (1990) Diab Med 7:360

2. Österreichisches Statistisches Zentralamt (1990) Demographisches Jahrbuch 1989. Osterreichische Staatsdruckerei, Wien

3. World Health Organization (1985) Diabetes mellitus. WHO, Geneva, Technical Report Series 727

4. Liniger C, Albeanu A, Bloise D, Assal JP (1990) The tuning fork revisited. Diab Med 7: 859-864

5. Weiss H (1988) Validity of routine ophthalmic photography by a non-mydriatic polaroid fundus camera as a screening procedure for early retinal abnormalities in patients with diabetes mellitus. Pediatr Adolesc Endocr 17: 138-146

6. Chantelau E, Zwecker M, Weiss H, Kluxen G, Berger M (1989) Fundus polaroid screening for diabetic retinopathy. Is one print per patient enough? Diab Care 12:223-226

7. Sawicki PT, Heinemann L, Berger M (1989) Comparison of methods for determination of microalbuminuria in diabetic patients. Diab Med 6: 412 415 
8. Gredler B, Kunze M (1983) Diabetes mellitus-Daten zur epidemiologischen Situation in Österreich. Akt Ernähr 8: 77-79

9. Michaelis D (1985) Zur Prävention des Diabetes mellitus unter Berücksichtigung epidemiologischer und ätiopathogenetischer Aspekte. Z Ges Inn Med 40: 473-479

10. Klein R, Klein BEK, Moss SE, DeMets DL, Kaufman I, Voss PS (1984) Prevalence of diabetes mellitus in southern Wisconsin. Am J Epidemiol 119: 54-61

11. Klein R, Klein BEK, Moss SE, Davis MD, DeMets DL (1984) The Wisconsin epidemiologic study of diabetic retinopathy. III. Prevalence and risk of diabetic retinopathy when age at diagnosis is 30 or more years. Arch Ophthalmol 102: 527-532

12. Klein R, Klein BEK, Moss SE (1984) Visual impairment in diabetes. Ophthalmology 91:1-9

13. French LR, Boen JR, Martinez AM, Bushhouse SA, Sprafka JM, Goetz FC (1990) Population-based study of impaired glucose tolerance and type II diabetes in Wadena, Minnesota. Diabetes 39: 1131-1137

14. Derfler K. Waldhäusl W, Zyman HJ, Howorka K, Holler C, Freyler H (1986) Diabetes care in rural area: clinical and metabolic evaluation. Diab Care 9: 509-517

15. Verhoeven S, van Ballegooie E, Casparie AF (1991) Impact of late complications in type 2 diabetes in a Dutch population. Diab Med 8:435-438

16. Ratzmann KP, Gorr K, Schneider H (1991) Untersuchungen zur Erblindungshäufigkeit bei Diabetes mellitus. Akt Endokr Stoffw 12: 138A (Abstract)

17. Kohner EM, Aldington SJ, Nugent Z (1987) Retinopathy at entry in the United Kingdom Prospective Diabetes Study (UKPDS) of maturity onset diabetes. Diabetes 36 (Suppl 1): $42 \mathrm{~A}$ (Abstract)

18. Davidson JK, Alogna M, Goldsmith M, Borden J (1981) Assessment of programme effectiveness at Grady Memorial Hospital Atlanta. In: Steiner G, Lawrence PA (eds) Educating diabetic patients. Springer, New York, pp 329-348

19. Assal JP, Mühlhauser I, Pernet A, Gfeller R, Jörgens V, Berger M (1985) Patient education as the basis for diabetes care in clinical practice and research. Diabetologia 28: 602-613

20. Falkenberg M (1990) Metabolic control and amputations among diabetics in primary health care: a population-based intensified program governed by patient education. Scand J Prim Health Care $8: 25-28$
21. Chantelau E, Kushner $T$, Spraul M (1990) How effective is cushioned therapeutic footwear in protecting diabetic feet? A clinical study. Diab Med 7:355-359

22. Standl R, Stiegler H, Rebell B et al. (1990) Der Typ-II-Diabetes in der Praxis des niedergelassenen Arztes: Konzept einer zentrumsunterstützten Betreuung und Ergebnisse einer Stichprobenerhebung im Großraum München. Akt Endokr Stoffw 11: 222-227

23. Mühlhauser I, Keim U, Hemmann D et al. (1989) Qualitätskontrolle der Langzeittherapie von älteren, insulinpflichtigen Diabetikern nach Teilnahme an einem stationären Diabetes-Behandlungs- und -Schulungsprogramm. Z Klin Med 44: 1221-1227

24. Mühthauser I, Santiago JV, Bolli GB (1988) The frequency of severe hypoglycaemia during intensive insulin therapy. Diab Nutr Metab 1:77-88

25. Stieber J, Hense HW, Döring A et al. (1991) Kardiovaskuläres Risikoprofil. Verlaufsdaten aus der MONICA-Studienregion Augsburg (1984/85 v.s. 1989/90). Münch Med Wochenschr 133 : $370-375$

26. Kronsbein P, Jörgens V, Mühlhauser I, Scholz V, Venhaus A, Berger M (1988) Evaluation of a structured treatment and teaching programme on non-insulin-dependent diabetes. Lancet II: $1407-$ 1411

27. Mühlhauser I, Sawicki P, Didjurgeit U, Jörgens V, Berger M (1988) Uncontrolled hypertension in Type 1 diabetes: assessment of patients' desires about treatment and improvement of blood pressure control by a structured treatment and teaching programme. Diab Med 5: 693-698

28. Mühlhauser I, Sawicki P, Didjurgeit U, Jörgens V, Berger M (1991) Evaluation of a hypertension treatment and teaching programme for patients with and without diabetes in general practice. Diabetologia 34 [Suppl 2]: A175 (Abstract)

Received: 30 September 1991

and in revised form: 11 December 1991

Dr. I. Mühlhauser

Medizinische Klinik der Universität Düsseldorf

Abteilung Stoffwechsel und Ernährung

Moorenstrasse 5

D-4000 Düsseldorf

FRG 